\title{
VARIABILITAS KONSENTRASI KLOROFIL-a DI BAGIAN BARAT PERAIRAN ACEH, INDONESIA BERDASARKAN PERGERAKAN ANGIN MONSUN
}

\section{THE VARIABILITY OF CHLOROPHYLL-a CONCENTRATION IN THE WESTERN PART OF ACEH WATERS, INDONESIA BASED ON MONSOON MOVEMENT}

\author{
Imamshadiqin $^{1}$, Imanullah $^{1}$, Erniati $^{1}$, Erlangga $^{1}$, Yudho Andika ${ }^{1}$, Salmarika $^{2}$, Roza Yusfiandayani $^{3}$ \\ ${ }^{1}$ Program Studi Ilmu Kelautan, Fakultas Pertanian, Universitas Malikussaleh \\ ${ }^{2}$ Program Studi Pemanfaatan Sumberdaya Perikanan, Fakultas Kelautan dan Perikanan, Universitas Syiah Kuala \\ ${ }^{3}$ Departemen Pemanfaatan Sumberdaya Perairan, Fakultas Perikanan dan Ilmu Kelautan, IPB University \\ Korespondensi: imamshadiqin@unimal.ac.id
}

\begin{abstract}
The waters of the western part of Aceh are located in the eastern part of the Indonesian Ocean. This area is a dynamic waters because it is part of Indonesian waters which is located between two continents and two oceans. The concentration of chlorophyll-a varies monthly basis in these waters. This study observed variability of chlorophyll-a concentration based on monsoon circulation. Analysis of chlorophyll-a concentration can be used to estimate the productivity of a waters. We found that the concentration of chlorophyll-a in the West Monsoon was higher than in the East Monsoon. In contrast, the concentration of chlorophyll-a in the East Monsoon was lower than in the West Monsoon.
\end{abstract}

Keywords: Aceh waters, chlorophyll-a, Monsoon

\begin{abstract}
ABSTRAK
Perairan Aceh bagian Barat terletak di bagian Timur Samudera Indonesia. Kawasan ini merupakan perairan yang dinamis karena merupakan bagian dari perairan Indonesia yang terletak di antara dua benua dan dua samudera. Konsentrasi klorofil-a bervariasi secara bulanan di perairan ini. Penelitian ini mengamati variasi konsentrasi klorofil-a berdasarkan sirkulasi angin muson. Analisis konsentrasi klorofil-a dapat digunakan untuk membantu perkiraan produktivitas sebuah perairan. Kami menemukan bahwa konsentrasi klorofil-a di Monsun Barat lebih tinggi daripada di Monsun Timur. Sebaliknya, konsentrasi klorofil-a di Monsun Timur lebih rendah dibandingkan di Monsun Barat.
\end{abstract}

Kata kunci: klorofil-a, Monsun, perairan Aceh 


\section{PENDAHULUAN}

Klorofil merupakan sekelompok pigmen hijau untuk membantu proses fotosintesis pada tumbuhan (Trujillo dan Thurman 2011). Konsentrasi klorofil-a membantu kita untuk mengidentifikasi produktivitas sebuah perairan (Nuzapril et al. 2017). Selain itu, konsentrasi klorofil-a juga membantu kita untuk mengidentifikasi peristiwa upwelling di buah perairan. Besaran konsentrasi klorofil-a ditunjukkan dalam miligram klorofil per meter kubik.

Upwelling merupakan pergerakan massa air secara vertikal dari lapisan bawah menuju lapisan atas (Kämpf dan Chapman 2016). Secara umum, upwelling dibangkitkan oleh angin yang kemudian menyebabkan terjadinya transpor Ekman (Trujillo dan Thurman 2011).

Monsun atau monsoon berasal dari bahasa Arab "Mausam" yang berarti musim. Monsun didefinisikan sebagai perubahan arah gerakan angin selama satu tahun atau musiman dan merupakan sistem sirkulasi regional.

Perairan Indonesia sangat terkait dengan sistem monsun. Ini disebabkan posisi Indonesia yang terletak diantara dua samudera besar dan benua (Sachoemar 2015). Indonesia memiliki dua jenis monsun yaitu Monsun Timur dan Monsun Barat. Monsun Timur terjadi pada bulan Juni hingga Agustus. Sedangkan Monsun Barat terjadi para Bulan Desember hingga Januari. Konsentrasi klorofil-a di perairan utara Selat Malaka pada monsun timur laut lebih tinggi daripada monsun barat daya (Tan et al. 2006).

Konsentrasi klorofil-a disebuah kawasan perairan, memiliki keterkaitan dengan musim (Syamsuddin et al. 2013). Untuk itu, kajian ini mengamati variabilitas bulanan konsentrasi klorofil-a berdasarkan siklus monsun di perairan Barat Aceh.

\section{METODE PENELITIAN}

Wilayah penelitian terletak di Samudra Hindia Timur, perairan barat Provinsi Aceh, terbentang antara $05-07^{\circ} \mathrm{N}$ dan $90-95^{\circ} \mathrm{E}$. Lokasi penelitian ditunjukkan pada Gambar 1.

Data bulanan konsentrasi klorofil-a diperoleh dari http://gdata1.sci.gsfc. nasa.gov/. Data angin diperoleh dari NCEP (National Centers for Environmental Prediction). Data klorofil-a dan data angin yang digunakan adalah data tahun 1998 sampai 2010. Data klorofil-a diolah menggunakan perangkat lunak Ocean Data View, versi 4.7 - 2015 (Schlitzer R. Ocean Data View, http://www.odv.awi.de). Hasil pengolahan data akan ditampilkan dalam gambar 2 dimensi. Selain ditampilkan dalam gambar 2 dimensi, data angin juga ditampilkan dalam bentuk grafik untuk mengetahui variabilitas bulanan dari konsentrasi klorofil-a tersebut.

Data angin dalam penelitian ini diolah dengan menggunakan software grads dan juga ditampilkan dalam gambar 2 dimensi. Data angin dalam penelitian ini, digunakan untuk mengetahui profil pergerakan angin monsun di Indonesia khususnya perairan Barat Aceh.

\section{HASIL DAN PEMBAHASAN}

\section{Pergerakan angin}

Dalam satu tahun, Indonesia mengalami dua sirkulasi pergerakan angin monsun. Pada Bulan Juni hingga Agustus, angin bergerak dari arah Timur. Sebaliknya, pada bulan Desember hingga Januari angin Muson bergerak dari arah Barat. Profil pergerakan angin pada periode Juni hingga Agustus dapat dilihat pada Gambar 2.

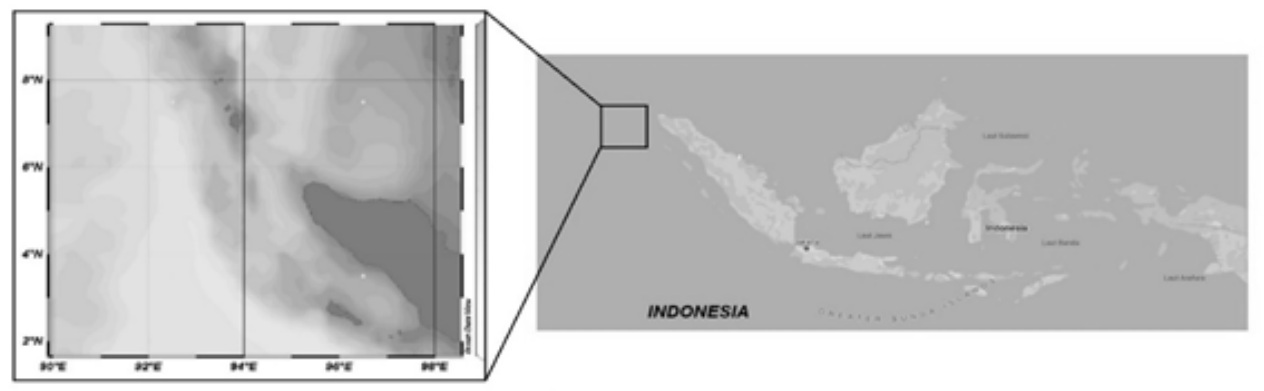

Gambar 1. Lokasi penelitian 


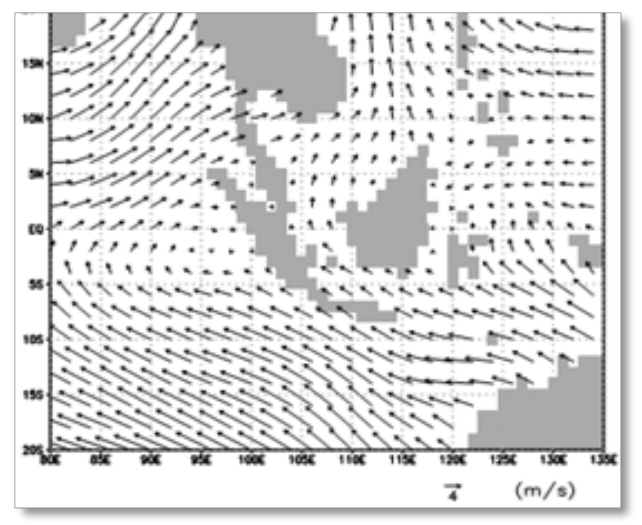

Gambar 2. Pergerakan Angin Periode Juni hingga Agustus

Gambar 2 menunjukkan bahwa pada angin muson Timur (Juni hingga Agustus) bergerak dari barat daya ke timur laut. Pergerakan angin ini melemah mulai Bulan September hingga Oktober. Periode ini, angin yang bergerak melewati daerah yang memiliki sedikit uap air. Sehingga Indonesia mengalami musim kemarau pada musim tersebut.

Gambar 3 merupakan profil pergerakan angin muson Barat. Pada Bulan Desember hingga Februari angin bergerak dari arah timur laut menuju barat daya. Bulan Maret hingga Mei kecepatan angin muson Barat ini melemah. Pada periode ini, angin yang bergerak melewati perairan yang luas sehingga pergerakan angin tersebut mengandung banyak uap air. Kondisi tersebut mengakibatkan kawasan Indonesia khususnya wilayah Barat mengalami musim hujan.

\section{Profil konsentrasi klorofil-a}

Klorofil-a adalah pigmen yang mampu melakukan fotosintesis dan terdapat di seluruh organisme fitoplankton. Kandungan klorofil-a pada fitoplankton dalam air menggambarkan jumlah fitoplankton dalam suatu perairan. Profil nilai rata-rata konsentrasi klorofil-a di perairan Barat Aceh dapat dilihat pada Gambar 4.

Gambar 4 memperlihatkan bahwa nilai konsentrasi klorofil-a bervariasi setiap monsun. Konsentrasi klorofil a pada Monsun timur lebih rendah dari pada Monsun Barat. Selama monsun Timur, nilai rata-rata konsentrasi klorofil-a berkisar $0,12 \mathrm{mg} / \mathrm{m}^{3}$ sampai $0,18 \mathrm{mg} / \mathrm{m}^{3}$. Nilai ratarata konsentrasi klorofil-a pada monsun Barat berkisar antara $0,14 \mathrm{mg} / \mathrm{m}^{3}$ sampai $0,25 \mathrm{mg} / \mathrm{m}^{3}$.

Perbandingan konsentrasi klorofil-a antara musim (monsun) Barat dan Timur dalam bentuk 2 dimensi dapat dilihat pada Gambar 5 .

Gambar 5 menunjukkan perbedaan antara konsentrasi klorofil-a di perairan Barat Aceh antara musim Barat dan musim Timur. Konsentrasi klorofil-a pada Musim Barat sebagaimana ditunjukkan pada Gambar 5, lebih tinggi daripada konsentrasi klorofil-a pada Musim Timur.

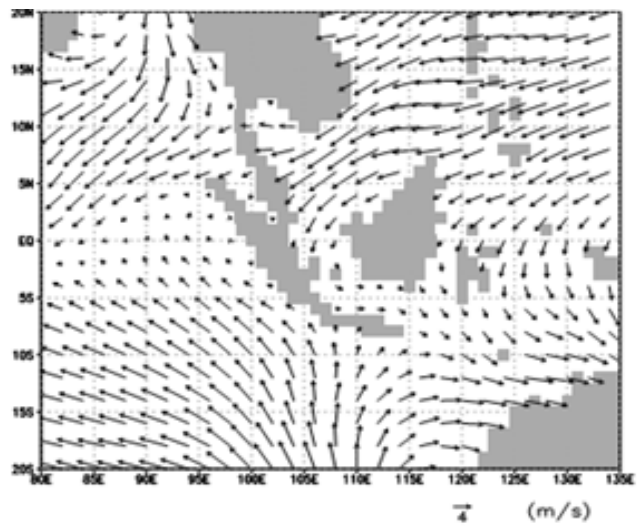

Gambar 3. Pergerakan angin periode Desember-Januari 


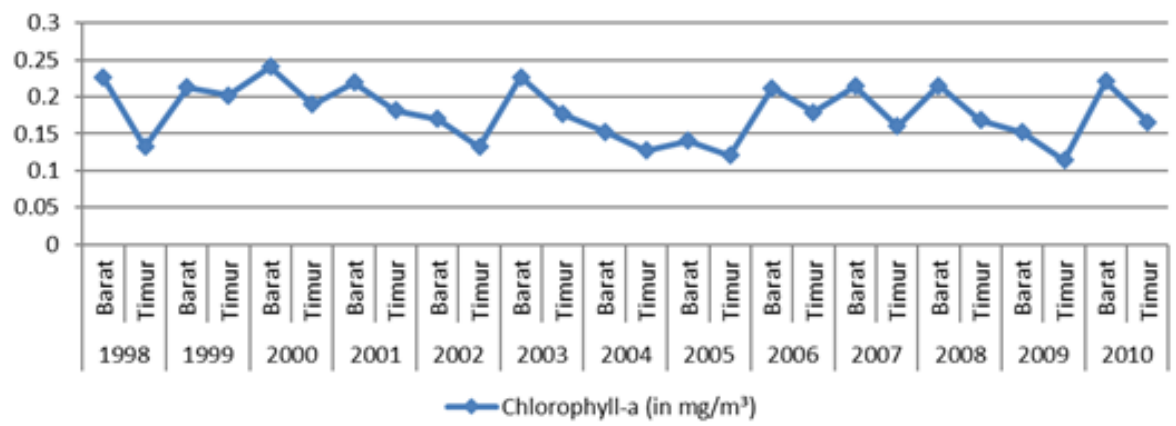

Gambar 4. Variasi konsentrasi rata-rata klorofil-a tahun 1998 hingga 2010

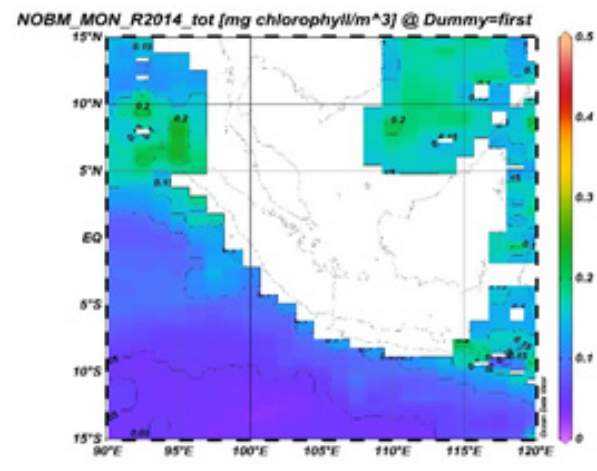

(a)

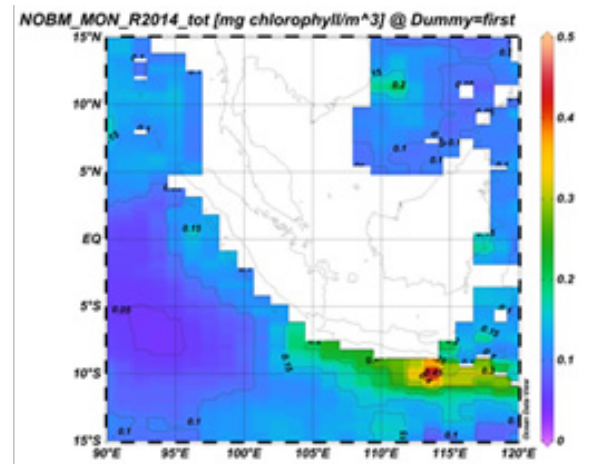

(b)

Gambar 5. (a) Konsentrasi klorofil-a Januari (Musim Barat); (b) Konsentrasi klorofil-a Bulan Juli (Musim Timur)

\section{KESIMPULAN DAN SARAN}

\section{Kesimpulan}

Penelitian mengenai variasi konsentrasi klorofil-a berdasarkan sirkulasi monsun di perairan Barat Aceh menghasilkan beberapa kesimpulan sebagai berikut, variasi konsentrasi klorofil-a di perairan Barat Aceh bervariasi di setiap bulan dan nilai klorofil-a pada musim barat lebih tinggi dibandingkan dengan musim timur.

\section{Saran}

Perlu ada penelitian lanjutan yang mengkaji korelasi antara pergerakan angin muson terhadap konsentrasi klorofil-a dan sejauh mana korelasi tersebut terjadi.

\section{DAFTAR PUSTAKA}

Kämpf J, Chapman P. 2016. Upwelling Systems of the World: A Scientific Journey to the Most Productive Marine Ecosystems. Cham: Springer. Nuzapril M, Susilo SB, Panjaitan JP. 2017.
Hubungan Antara Konsentrasi Klorofil-a dengan Tingkat Produktivitas Primer Menggunakan Citra Satelit Landsat-8. Jurnal Teknologi Perikanan dan Kelautan. 8(1): 105-114.

Sachoemar S. 2015. Variability of Sea Surface Chlorophyll-a, Temperature, and Fish Catch within Indonesian Region Revealed by Satellite Data. Marine Research in Indonesia. 37(2): 75-87.

Syamsuddin ML, Saitoh S, Hirawake T, Bachri S, Harto AB. 2013. Effects of El Niño-Southern Oscillation Events on Catches of Bigeye Tuna (Thunnus obesus) in the Eastern Indian Ocean off Java. Fishery Bulletin. 111(2): 175-188. 10.7755/FB.111.2.5.

Tan CK, Ishizaka J, Matsumura S, Yusoff FM, Mohamed MIH. 2006. Seasonal Variability of SeaWiFS Chlorophyll-a in the Malacca Straits in Relation to Asian Monsoon. Continental Shelf Research. 26(2): 168-178.

Trujillo AP, Thurman HV. 2011. Essentials of Oceanography, Pearson Prentice Hall, United States. pp. 204-205. 